Thorax (1975), 30, 543.

\title{
Effect of atropine on sputum production
}

\author{
M. T. L O P E Z - V I D R I E R O, J . C O S T E L L O ${ }^{1}$, \\ T. J . H . C L A R K, I. D A S, E. E . K E A L, \\ a n d L. R E I D \\ Department of Experimental Pathology, Cardiothoracic Institute, Brompton Hospital, \\ London SW3 and Department of Medicine ${ }^{1}$, The Royal Infirmary, Edinburgh
}

\begin{abstract}
Lopez-Vidriero, M. T., Costello, J., Clark, T. J. H., Das, I., Keal, E. E., and Reid, Lynne (1975). Thorax, 30, 543-547. Effect of atropine on sputum production. The effect of atropine on sputum production has been studied in patients with asthma, chronic bronchitis, and bronchiectasis in some of whom there was bronchorrhoea. In three patients a reduction in sputum volume was observed after atropine but it would seem that the decrease was mainly due to the inhibitory effect on salivary secretion which facilitates spitting. The one patient treated with long-term oral atropine showed a marked reduction in sputum volume although chemical constituents and viscosity levels remained unchanged, suggesting that in this case atropine had an inhibitory effect on bronchial gland secretion.
\end{abstract}

In recent years attention has been focused on the role played by the parasympathetic nervous system in non-antigenic and antigenic-induced bronchoconstriction. Studies carried out in laboratory animals and in asthmatic and chronic bronchitic patients (Hume and Rhys, 1961; Sterling, 1967; Simonsson, Jacobs, and Nadel 1967; Yu, Galant, and Gold, 1972) have shown that stimulation of irritant receptors by citric acid, charcoal dust, cold air, histamine aerosol, cigarette smoke, rapid respiratory manoeuvres or antigen challenge result in bronchoconstriction, and that this reflex bronchoconstriction is largely blocked by atropine.

Atropine has long been used to inhibit salivary and bronchial secretion and, indirectly, laryngospasm before administration of an anaesthetic (Eger, Kraft, and Keasling, 1961; Freeman and Bachman, 1959; Pohto and Ahtee, 1966). Organ culture studies carried out with human bronchial explants (Sturgess and Reid, 1972a and b) have shown that atropine reduces the secretory activity of mucous and serous glands, although complete inhibition was not achieved.

Since the beginning of the 19th century (Sigmond, 1836) atropine has been used, either alone or in combination with other bronchodilators, in the treatment of reversible airways obstruction (Beakey et al., 1949; Dautreband and Heymans, 1959; Chamberlain, Muir, and Kennedy, 1962; Yu et al., 1972) but the reports that it slows mucous transport rate and ciliary beating (Blair and Woods, 1969) and may alter the physical properties of the mucus layer (Basch, Holinger, and Poncher, 1941) have restricted its clinical use.

It has been widely accepted that atropine increases the viscosity of bronchial secretion and impairs the ciliary clearing, thus causing retention of mucus and airways obstruction, but there is little evidence to support this. The effect of atropine on bronchial secretions of bronchiectatic patients was studied during bronchoscopy (Basch et al., 1941) and less, but more viscous, secretion adherent to the bronchial mucosa was reported. Blanshard (1960) reported no change in sputum viscosity in postoperative patients with chronic bronchitis before or after atropine.

Our study was designed to assess the effect of atropine on sputum volume, viscosity, and chemical constituents in a group of patients with airflow obstruction from various causes.

\section{PATIENTS AND METHODS}

Nine male patients who complained of constant cough and sputum were studied; their ages ranged from 18 to 80 years, the mean being 46.2 years (Table I). Five of these had asthma, two had bronchiectasis, and two had chronic bronchitis (Medical Research Council, 1965).

The patients were selected because they produced sputum rather than for the underlying 
T A B L E I

DETAILS OF CLINICAL FEATURES AND DRUG ADMINISTRATION

\begin{tabular}{|c|c|c|c|c|c|c|}
\hline \multirow[t]{3}{*}{ Patient } & \multirow[t]{3}{*}{ Age } & \multirow[t]{3}{*}{ Sex } & \multirow[t]{3}{*}{ Diagnosis } & \multicolumn{3}{|c|}{ Atropine Administration } \\
\hline & & & & \multirow{2}{*}{ Route } & \multicolumn{2}{|c|}{ Dose (mg bd) } \\
\hline & & & & & Day 1 & Day 2 \\
\hline $\begin{array}{l}1 \\
2 \\
3 \\
4 \\
5 \\
6 \\
7 \\
8 \\
9\end{array}$ & $\begin{array}{l}44 \\
48 \\
80 \\
53 \\
18 \\
46 \\
49 \\
36 \\
42\end{array}$ & $\begin{array}{l}\mathbf{M} \\
\mathbf{M} \\
\mathbf{M} \\
\mathbf{M} \\
\mathbf{M} \\
\mathbf{M} \\
\mathbf{M} \\
\mathbf{M} \\
\mathbf{M}\end{array}$ & $\begin{array}{l}\text { Intrinsic asthma + bronchorrhoea } \\
\text { Extrinsic asthma } \\
\text { Chronic bronchitis } \\
\text { Extrinsic asthma } \\
\text { Bronchiectasis } \\
\text { Chronic bronchitis } \\
\text { Intrinsic asthma }+ \text { bronchorrhoea } \\
\text { Bronchiectasis }+ \text { bronchorrhoea } \\
\text { Intrinsic asthma }\end{array}$ & $\begin{array}{l}\text { Oral } \\
\text { Inhalation } \\
\text { Intramuscular } \\
\text { Inhalation } \\
\text { Intramuscular } \\
\text { Inhalation } \\
\text { Intramuscular } \\
\text { Intramuscular } \\
\text { Intramuscular }\end{array}$ & $\begin{array}{l}0.3 \\
1.2 \\
0 \cdot 6 \\
2 \cdot 0 \\
1 \cdot 2 \\
1.2 \\
0.6 \\
0.6 \\
0.6\end{array}$ & $\begin{array}{l}0 \cdot 3 \\
2 \cdot 4 \\
2 \cdot 0 \\
1 \cdot 2 \\
1 \cdot 2 \\
1 \cdot 2 \\
0 \cdot 6 \\
0 \cdot 6\end{array}$ \\
\hline
\end{tabular}

cause of this. Since patients 1,7 , and 8 produced over $100 \mathrm{ml}$ of sputum daily, they were considered to have bronchorrhoea also (Keal, 1971; Lopez-Vidriero et al., in preparation); bronchorrhoea was associated with intrinsic asthma in two patients and with bronchiectasis in one.

Atropine was administered by inhalation in three patients (via a Wright's nebulizer), by intramuscular injection in five patients, and orally in one patient (Table I). The inhaled and intramuscular atropine was administered between 09.30 and 10.00 hours on the treatment day. Atropine methonitrate was used for inhalation, and atropine sulphate for oral and intramuscular administration. If the patient did not have a dry mouth or a greater than $10 \%$ rise in pulse rate after the first dose of atropine, the dose was doubled the next day (patients 2 and 7, Table I) and, in this way, atropine effect was induced in every patient. Patient 5 was studied as an outpatient and did not have his pulse rate recorded. Patient 1 had long-term oral atropine.

SPUTUM STUdies The daily sputum volume was measured, and sputum samples were collected at three-hour intervals from 06.00 to 21.00 hours on the day of atropine administration and two or three days before treatment. The sputum proo duced from 06.00 to 15.00 hours was used for viscosity and chemical studies, using a Ferrantio Shirley viscometer, over a shear rate of $0-180 \oplus$ $\sec ^{-1}$.

The remainder of the sputum was frozen at $-20^{\circ} \mathrm{C}$ and stored at the same temperature untib chemical analysis was carried out. Preliminaryor treatment of sputum included boiling at $100^{\circ} \mathrm{C}$ for 10 minutes to destroy salivary and bacteria enzymes (neuraminidase and aldolase) and dialysis (Visking tube 18/32) against distilled water ad $4^{\circ} \mathrm{C}$ for 72 hours. The following chemical estima tions were carried out: macromolecular materia (Warren, 1959), N-acetyl-neuraminic acid (Waro ren, 1959), and methyl-pentose-fucose (Gibbons 1955).

\section{RESULTS}

VOLUME The mean values for the 24-hour and three-hour sputum volumes after atropine treat. ment were compared with mean values obtaine $\$$ during control days. Two patients ( 3 and 9, Table II) failed to produce any sputum in the thre? hours after intramuscular atropine sulphate $(0.6 \mathrm{mg})$ but, in both, the amount expectorate

T A B L E I I

EFFECT OF ATROPINE ON SPUTUM VOLUME AND VISCOSITY

\begin{tabular}{|c|c|c|c|c|c|c|c|c|c|c|}
\hline \multirow[b]{3}{*}{ Patient } & \multicolumn{6}{|c|}{ Sputum Volume (ml) } & \multicolumn{4}{|c|}{$\begin{array}{l}\text { Apparent Viscosity at } \\
1350 \mathrm{sec}-1 \text { (poise) }\end{array}$} \\
\hline & \multicolumn{3}{|c|}{ Control Day } & \multicolumn{3}{|c|}{ Atropine Day } & \multicolumn{2}{|c|}{ Control Day } & \multicolumn{2}{|c|}{ Atropine Day } \\
\hline & $\underset{\mathrm{hr}}{06-09}$ & $\begin{array}{c}09-12 \\
\mathrm{hr}\end{array}$ & Daily & $\underset{\mathrm{hr}}{06-09}$ & $\begin{array}{c}\text { 09-12 } \\
\mathrm{hr}\end{array}$ & Daily & $\begin{array}{c}06-09 \\
\mathrm{hr}\end{array}$ & $\begin{array}{c}09-12 \\
\mathrm{hr}\end{array}$ & $\underset{\mathrm{hr}}{06-09}$ & $\begin{array}{c}\text { 09-12 } \\
\text { hr }\end{array}$ \\
\hline $\begin{array}{l}1 \\
2 \\
3 \\
4 \\
5 \\
6 \\
7 \\
8 \\
9\end{array}$ & $\begin{array}{r}54 \\
7 \\
2 \\
9 \\
10 \\
2 \\
12 \\
50 \\
1\end{array}$ & $\begin{array}{c}12 \\
5 \\
2 \\
2 \cdot 5 \\
7 \\
2 \\
11 \\
18 \\
0.5\end{array}$ & $\begin{array}{r}170 \\
84 \\
12 \\
36 \\
38 \\
12 \\
105 \\
203 \\
4\end{array}$ & $\begin{array}{r}7 \\
11 \\
1 \\
8 \\
30 \\
3 \\
16 \\
50 \\
1\end{array}$ & $\begin{array}{r}4 \\
14 \\
3 \\
22 \\
1 \\
15 \\
5 \\
-\end{array}$ & $\begin{array}{r}25 \\
104 \\
10 \\
30 \\
65 \\
10 \\
132 \\
301 \\
3\end{array}$ & $\begin{array}{l}0.37 \\
0.28 \\
0.97 \\
0.61 \\
0.69 \\
3.11 \\
0.32 \\
0.15 \\
0.10\end{array}$ & $\begin{array}{l}0.09 \\
0.11 \\
0.58 \\
0.12 \\
2.29 \\
1.54 \\
0.28 \\
0.05 \\
0.11\end{array}$ & $\begin{array}{l}0.28 \\
0.29 \\
0.82 \\
0.39 \\
1 \cdot 14 \\
2.35 \\
0.32 \\
0.24 \\
0.26\end{array}$ & $\begin{array}{c}0.04 \\
0.07 \\
0.73 \\
2.47 \\
1.43 \\
0.62 \\
0.06 \\
-\end{array}$ \\
\hline
\end{tabular}


T A B L E I I I

EFFECT OF ATROPINE ON CHEMICAL CONSTITUENTS

\begin{tabular}{|c|c|c|c|c|c|c|c|c|c|c|c|c|}
\hline \multirow[b]{3}{*}{ Patient } & \multicolumn{4}{|c|}{ Dry Weight (mg/ml) } & \multicolumn{4}{|c|}{ Neuraminic Acid (mg/ml) } & \multicolumn{4}{|c|}{ Fucose $(\mathrm{mg} / \mathrm{ml})$} \\
\hline & \multicolumn{2}{|c|}{ Control Day } & \multicolumn{2}{|c|}{ Atropine Day } & \multicolumn{2}{|c|}{ Control Day } & \multicolumn{2}{|c|}{ Atropine Day } & \multicolumn{2}{|c|}{ Control Day } & \multicolumn{2}{|c|}{ Atropine Day } \\
\hline & $\begin{array}{c}06-09 \\
\mathrm{hr}\end{array}$ & $\begin{array}{c}09-12 \\
\mathrm{hr}\end{array}$ & $\begin{array}{c}06-09 \\
\mathrm{hr}\end{array}$ & $\begin{array}{c}\text { 09-12 } \\
\mathrm{hr}\end{array}$ & $\begin{array}{c}06-09 \\
\mathrm{hr}\end{array}$ & $\begin{array}{c}09-12 \\
\mathrm{hr}\end{array}$ & $\begin{array}{c}06-09 \\
\mathrm{hr}\end{array}$ & $\begin{array}{c}09-12 \\
\mathrm{hr}\end{array}$ & $\underset{\mathrm{hr}}{06-09}$ & $\underset{\mathrm{hr}}{09-12}$ & $\underset{\mathrm{hr}}{06-09}$ & $\underset{\mathrm{hr}}{09-12}$ \\
\hline $\begin{array}{l}1 \\
2 \\
3 \\
4 \\
5 \\
6 \\
7 \\
8 \\
9\end{array}$ & $\begin{array}{r}8 \cdot 30 \\
8 \cdot 48 \\
45 \cdot 75 \\
13 \cdot 61 \\
58 \cdot 46 \\
33 \cdot 80 \\
15 \cdot 15 \\
9 \cdot 33 \\
7 \cdot 35\end{array}$ & $\begin{array}{r}6 \cdot 10 \\
6 \cdot 39 \\
51 \cdot 27 \\
7 \cdot 50 \\
87 \cdot 39 \\
37 \cdot 10 \\
21 \cdot 54 \\
9 \cdot 72 \\
5 \cdot 70\end{array}$ & $\begin{array}{r}16 \cdot 58 \\
13 \cdot 81 \\
61 \cdot 80 \\
14 \cdot 54 \\
48 \cdot 78 \\
42.50 \\
13.47 \\
6.22 \\
8.40\end{array}$ & $\begin{array}{r}6.90 \\
8.13 \\
10.73 \\
80.75 \\
48.07 \\
21.40 \\
8.62 \\
-\end{array}$ & $\begin{array}{l}0.21 \\
0.39 \\
1.31 \\
0.84 \\
0.69 \\
3.80 \\
0.72 \\
0.30 \\
0.31\end{array}$ & $\begin{array}{l}0.21 \\
0.18 \\
1.72 \\
0.38 \\
1.70 \\
2.80 \\
0.73 \\
0.45 \\
0.21\end{array}$ & $\begin{array}{l}0.21 \\
0.68 \\
1.90 \\
1.10 \\
0.73 \\
2.38 \\
1.06 \\
0.29 \\
0.26\end{array}$ & $\begin{array}{l}0.26 \\
0.35 \\
\overline{0.55} \\
0.96 \\
1.60 \\
1.02 \\
0.32 \\
-\end{array}$ & $\begin{array}{l}0.26 \\
0.50 \\
0.68 \\
0.46 \\
1.30 \\
1.50 \\
0.48 \\
0.23 \\
0.33\end{array}$ & $\begin{array}{l}0.15 \\
0.30 \\
0.71 \\
0.23 \\
0.87 \\
1.50 \\
0.62 \\
0.33 \\
0.31\end{array}$ & $\begin{array}{l}0.37 \\
0.96 \\
0.92 \\
0.49 \\
0.97 \\
1.40 \\
0.51 \\
0.25 \\
0.34\end{array}$ & $\begin{array}{l}0.22 \\
0.52 \\
0.30 \\
0.88 \\
1.50 \\
0.74 \\
0.32 \\
-\end{array}$ \\
\hline
\end{tabular}

before atropine was very small -1 and $2 \mathrm{ml}$ respectively, and the 24-hour volume remained within control values. These two patients complained of marked dryness of mouth and difficulty in coughing up phlegm from the back of the throat. Another patient (8), in whom atropine seemed to have some effect, had bronchiectasis and was thought to have bronchorrhoea, although our studies showed that the 'sputum' was mainly saliva. He showed a significant reduction in the three-hour sputum volume, but the 24-hour volume remained within the control range (Table II).

VISCOSITY AND CHEMICAL RESULTS Neither viscosity nor chemical constituents were consistently affected by atropine (Tables II and III).

For each individual patient the levels for apparent viscosity at a shear rate of $1350 \mathrm{sec}^{-1}$ and for chemical constituents-dry weight, neuraminic acid, and fucose concentration-fell within the range for their disease group. In two patients (4 and 7, Table II) the apparent viscosity increased on the second day of atropine administration, and in patient 7 it coincided with an increase in the dose of atropine.

There was no significant difference, even at the $10 \%$ level, between the results obtained for sputum volume, viscosity, and chemical constituents for the corresponding periods on control and treatment days, nor was there any significant difference before and after treatment on the treatment day itself.

RESPONSE OF BRONCHORRHOEA TO LONG-TERM ATROPINE In patient 1 (Table II) the effect was noted after long-term atropine. He had been receiving corticosteroid treatment, $10 \mathrm{mg} /$ day, for the previous five years. Two months before atropine was started, prednisone had been increased to $35 \mathrm{mg}$ daily and he was also given beclomethasone dipro- pionate, $200 \mu \mathrm{g}$ four times a day, but no effect on sputum volume was observed. When oral atropine was started, prednisone was increased to $60 \mathrm{mg}$ daily but then gradually reduced to only $10 \mathrm{mg}$. Atropine was started at a dose of $0.3 \mathrm{mg}$ twice daily and was gradually increased during the five weeks study period to $0.6 \mathrm{mg}$ four times a day (Figure). The 24-hour sputum volume showed a marked reduction during the last three weeks of the study when atropine levels were at their highest and prednisone levels at their lowest. Chemical constituents and viscosity, even of the small amount of residual sputum, did not change and fell within the values found for prostaglandin $\mathbf{F}_{\mathbf{2}}{ }^{a}$-stimulated bronchial secretion (LopezVidriero et al., in preparation).
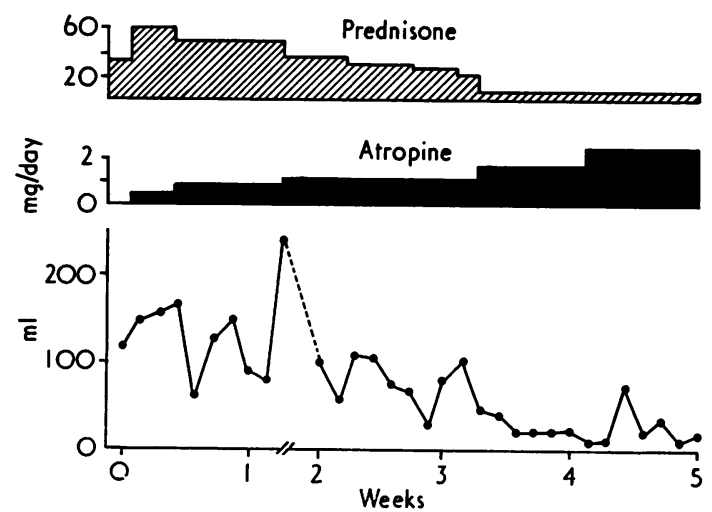

FIGURE Reduction in sputum volume in patient 1 by atropine after failure to respond to prednisone.

\section{DISCUSSION}

Our study confirms Blanshard's (1960) findings since viscosity and also dry weight yield, neuraminic acid, and fucose varied little after atropine.

Since studies of the human bronchial glands in organ culture (Sturgess and Reid, 1972a and b) 
have shown that atropine has a depressant effect on the secretion from both mucous and serous cells of the submucosal glands, it is somewhat surprising that our studies revealed practically no effect on the volume and constituents of secretion. On the other hand, organ culture studies also showed that gland hypertrophy affects sensitivity to drugs; that is, the larger the gland-expressed as a gland/wall ratio (Reid, 1960)-the less the inhibitory effect of a given dose of atropine.

The two patients in whom secretion dried up produced small amounts of sputum and, presumably, had little if any gland hypertrophy: both complained of marked dryness of the mouth. It seems that in these patients the effect of atropine was mainly on the salivary secretion, thus affecting the expulsion of bronchial secretion by reducing the 'lubricating action' of saliva, as reported by Hillis (1952). The reduction in sputum volume observed in one patient with 'bronchorrhoea' associated with bronchiectasis could also be explained by the inhibitory effect of atropine on salivary secretion since our studies showed that most of the 'sputum' produced had chemical and rheological characteristics of saliva.

The features of the response of the patient with bronchorrhoea to long-term atropine are different from the pattern of response to prednisone described by Keal (1971). In some of Keal's patients with bronchorrhoea associated with asthma, a fall in sputum volume was accelerated by prednisone, and the concentration of dry weight and neuraminic acid suggested an increased concentration of the secretion, perhaps by altering the tissue fluid component. In the present study the decrease in sputum volume after atropine, without any change in chemical constituents, suggests an inhibitory effect on bronchial gland secretion. Since the patient on oral atropine had intrinsic asthma, minimal gland hypertrophy would be expected and this should be susceptible to inhibition by atropine. It seems that excessive bronchial secretion may be of two types-one susceptible to atropine and the other to prednisone.

\section{REFERENCES}

Basch, F. P., Holinger, P., and Poncher, H. G. (1941). Physical and chemical properties of sputum. II. Influence of drugs, steam, carbon dioxide and oxygen. American Journal of Diseases of Childhood, $62,1149$.

Beakey, J. F., Bresnick, E., Levison, L., and Segal, M. S. (1949). Evaluation of therapeutic substances employed for relief of bronchospasm; anticholinergic agents. Annals of Allergy, 7, 113.

Blair, A. M. and Woods, A. (1969). The effects of isoprenaline, atropine and dysodium cromogi cate on ciliary motility and mucus flow in vim in cat. British Journal of Pharmacology, 35, 379.

Blanshard, G. (1960). Sputum viscosity and pos operative pulmonary atelectasis. Diseases of the Chest, 37, 75.

Chamberlain, D. A., Muir, D. C., and Kennedy, K. $\overrightarrow{\mathrm{B}}$ (1962). Atropine methonitrate and isoprenaline in bronchial asthma. Lancet, $2,1019$.

Dautreband, L. and Heymans, C. (1959). New studiês on aerosols; comparative action of atropine and of sympathomimetic drugs upon pneumos constricting effects of parasympathomimetie substances. Archives Internationale de Pharmac\&] dynamie et de Therapie, 120, 433.

Eger, E. I., Kraft, I. D., and Keasling, H. H. (196f Comparison of atropine or scopolamine plus pentobarbital, meperidine or morphine as pediatric pre-anesthetic medication. Anesthesiolog 22, 962 .

Freeman, A. and Bachman, L. (1959). Evaluation preoperative medication in children. Anesthestu and Analgesia, 38, 429.

Gibbons, M. N. (1955). The determination of methxy pentoses. A nalyst, 80, 268.

Hillis, B. R. (1952). The assessment of cough suppres sing drugs. Lancet, 1, 1230.

Hume, K. M. and Rhys, E. J. (1961). Response bronchodilators in intrinsic asthma. Quarter, Journal of Medicine, 30, 189.

Keal, E. (1971). Biochemistry and rheology of sputu in asthma. Postgraduate Medical Journal, 47, 179 .

Lopez-Vidriero, M. T., Das, I., Smith, A. P., an Reid, L. (1975). Bronchial secretion from normat human airways after inhalation of prostaglandip $\mathrm{F}_{2}$-alpha, acetyl choline and histamine. (Su mitted for publication).

Medical Research Council (1965). Definition and classification of chronic bronchitis. Committe on the Aetiology of Chronic Bronchitis, Lancen; 1, 775 .

Pohto, P. and Ahtee, L. (1969). Effect of atropine, methyl atropine, methyl scopolamine and pilQcarpine on salivary secretion and heart rate in man. Annales Medicinae Experimentalis Biologiae Fenniae, 4, 411.

Reid, L. (1960). Measurement of the bronchia mucous gland layer: a diagnostic yardstick chronic bronchitis. Thorax, 15, 132.

Sigmond, G. G. (1836). Lectures on materia mediç and therapeutics now in course of delivery The Windmill School of Medicine, Lecture $1 \$$. Lancet, 2, 392.

Simonsson, B. G., Jacobs, F. M., and Nadel, J. (1967). Role of autonomic nervous system and the cough reflex in the increased responsiveness of airways in patients with obstructive airw disease. Journal of Clinical Investigation, 4\% 1812.

Sterling, G. M. (1967). Mechanism of bronchoco striction caused by cigarette smoking. British Medical Journal, 3, 275. 
Sturgess, J. and Reid, L. (1972a). Secretory activity of the human bronchial gland in vivo. Experimental and Molecular Pathology, 16, 362.

and - (1972b). The effect of drugs on the secretory activity of the human bronchial gland in organ culture. Clinical Science, 43, 533.

Warren, L. (1959). The thiobarbituric acid assay of sialic acids. Journal of Biological Chemistry, 234, 1971.
Yu, D. Y. C., Galant, S. P. and Gold, W. M. (1972). Inhibition of antigen-induced bronchoconstriction by atropine in asthmatic patients. Journal of Applied Physiology, 32, 823.

Requests for reprints to: Professor Lynne Reid, Department of Experimental Pathology, Cardiothoracic Institute, Brompton Hospital, London SW3. 